\title{
The Empirical Model on The Relationship among Price, Service Quality and Customer Purchasing Decision: The Case of the Dili Tais Market in Timor-Leste
}

\author{
Estanislau de Sousa Saldanha ${ }^{1}$ Agostinha Silva $^{2}$, Agustinus Nahak Seran ${ }^{3}$, Helio Brites da Silva ${ }^{4}$ \\ ${ }^{I}$ Senior Lecturer of the Master of Business Administration (MBA) Program, Dili Institute of Technology, Timor-Leste \\ ${ }^{2,3,4}$ School of Tourism and Hospitality, Dili Institute of Technology, Timor-Leste \\ Email: estanislausaldanha@yahoo.com; vekiela234@gmail.com; agustinusnahakbali@gmail.com; heliobrites11031980@gmail.com
}

\begin{abstract}
Price, service quality and purchasing decisions are played important roles in tourism market management. Therefore, many empirical studies have been carried out to enhance customer purchasing decisions through price and service quality. Nonetheless, there is a limited number of studies in emerging tourism destinations and marketing. This study aims to analyse the influence of price and service quality on customers' purchasing decisions. This research was carried out at the Tais Market, Kolmera, Dili. Data was collected by using questionnaires distributed to 395 respondents using accidental sampling technique, and hypotheses were tested using SMART-PLS 3.0. The results showed that both price and service quality have significant impacts on customers' purchasing decisions. This study enriches the empirical studies on price, service quality and customers' purchasing decisions, particularly in emerging tourism destinations and markets. This study implies that to enhance customers' purchasing decisions, the Tais Market needs to offer products at a reasonable and fair price as well to keep improving the tangible and intangible services.
\end{abstract}

Keywords: Price, service quality, purchasing decision, customer, Dili.

\section{Introduction}

Customer's purchasing decision is an important factor to determine market share and to increase company's profit. Customer's purchasing decisions are influenced by the quality of the products, services, price and product value by costumers. If companies offer better prices, products and services quality will enhance customer satisfaction (Kaswengi \& Lambey-Checchin, 2019; Philip \& Keller, 2016) and purchasing decision (Anderson et al., 2000; Jung \& Yoon, 2012; Maslowska et al., 2017; von Helversen et al., 2018). Therefore, companies seek to know customers' needs and want which link closely to the price and services.

Price refers to the quantity of money that is used to purchase a product or service (Zietsman et al., 2019), thus, price is one of the main indicators for customers' purchasing decisions (Hati et al., 2021). Customers always judge after purchasing a product. Therefore, determining product price should consider product quality and quantity in order to meet customer satisfaction, which in turn leads to enhance corporate's profitability. Therefore, price has great impacts on costumer purchasing decision. This has been confirmed by numerous empirical studies (Carvalho et al., 2020; Djatmiko \& Pradana, 2016). However, studies also shows that lower price does not correlate to the increasing costumer purchasing decision (Son \& Jin, 2019).

In addition to product price, services quality is always utilized by companies to attract customers, therefore, enhancing services quality will lead to provide a great impact to the increasing customers' satisfaction and loyalty (Kasiri et al., 2017; Subrahmanyam, 2017; Borishade et al., 2021) If customers loyal to a product, they will regularly purchase and recommend the product to the costumers. Therefore, service quality provides significant impact on customers' satisfaction (Chien \& Chi, 2019) and purchasing decisions (Carvalho et al., 2020).

There were mixing results of previous empirical studies on the relationship among price, services quality and customers' purchasing decisions (Song et al., 2019; Carvalho et al., 2020; Marcal et al., 2020). Therefore, researchers seek to search these relationships from different industries, culture and markets. However, there are limited empirical studies on price, service quality and costumer's purchasing decision in emerging market such as Timor-Leste. Therefore, this study aims to investigate how the price and services quality as essential factors to influence customers' purchasing decisions in "Tais Market" in Dili, Timor-Leste. The objectives of this study are to identify the influence of price and service quality on customers' purchasing decisions.

\section{Theoretical Frameworks, Research Model and Hypothesis}

\section{1.Price}

Price is usually an essential factor for customers in purchasing a product in the market, and the promotions of goods are always linked with varieties of prices in the market (Son \& Jin, 2019). Price is the value of a product which is well known as money. Price is also a quantity of money that is used to buy a product (Kotler et al., 2012). Generally, price is an option of customers' preferences to purchase a product 
in the company (Asadi et al., 2014). Thus, price must be fair; therefore, it could convince or attract customers to purchase any products (Zietsman et al., 2019).

Costumers could know the value of the product that they purchased when they know the price; thus, it could provide the benefits based on the quantity of money that they executed to buy a product or a service (Chen et al., 2005). Price is important for a company mostly in buying and selling activities because via price, company could provide the value of products that offer to costumers (Razak et al., 2017).

Besides the price is providing value and quantity of products, expensive and cheap prices also would link to customers' purchasing decisions (Razak et al., 2017). The cheap price tends to stimulate costumers' purchasing decisions. However, some previous studies found that the cheap prices could not enhance customers' willingness to purchase any products (Son \& Jin, 2019).

\section{2.Services quality}

Service quality has been link to costumer attitude as global evaluation on the service offered by an organization (Parasuraman et al., 1988; Kotler, 2000) which provides value creation to customers (Chien \& Chi, 2019). Service quality is services that individual or companies offer to meet costumer' expectation and satisfaction (Kotler \& Keller, 2012).

Numerous studies revealed that service quality is generally closely link to customer satisfaction, loyalty (Meesala \& Paul, 2018; Özkan et al., 2019), behaviour intention (Aliman \& Mohamad, 2016; Lee \& Kim, 2017), purchasing decision (Carvalho et al., 2020), and organization performance (Ramayah et al., 2011; Saldanha, 2019). Therefore, profit and nonprofit organizations are trying to offer products and services based on customer demands through high quality services.

Parasuraman et al. (1991) developed five dimensions of services quality to measure service quality. These dimensions are: (1) Reliability refers to the ability of a company to perform the service dependably and accurately. The company started providing services on its promisespromises without failure about delivery, service provisions, problem solutions and pricing. (2) Responsiveness refers to the ability of employees to help the customers' inquiries and provide prompt services. (3) Assurance refers to the employees' characteristics or behavior and also employees' knowledge of courtesy and the ability of the firm and its employees to inspire trust and confidence. Also, assurances mean the employees' respect and have the ability to respond to customers' problems or inquiries. (4) Empathy means a company has a well understanding of their customers' problems. Suppliers need to provide caring individualized attention to the firm provides its customers.

\section{3.Purchasing Decisions}

Purchase decision is the thought process that leads a consumer from identifying a need among all existing alternatives (Philip \& Keller, 2016). The purchase decision is also an action that led consumers to have references regarding all groups of products offered by a company; either customer will choose, use it or do not use it (Cavallone, 2017; Kotler et al., 2016). Purchasing decision is also the thought process that leads a consumer to make decisions whether to buy a product or not which is based on the previous experiences of using a product (Chen et al., 2017; De Medeiros et al., 2016; Jain et al., 2018; Jun \& Park, 2016).

Customers always have their personal information regarding the product previous price, before receiving that information from friends and relatives (Maslowska et al., 2017). This means that customers' previous experiences in purchasing a product have become a main personal reference to make better decisions to buy a product (Cheung et al., 2014). Customers also have many references to choose the better company that consumers most preferences to purchase a product (Anderson et al., 2000; Djatmiko \& Pradana, 2016; Hanna et al., 2019; Jain et al., 2018). The decisions to purchase were based on previous experiences. Therefore, previous experiences in purchasing products have become the main information for customers to make decisions ( Chen et al., 2017; Carvalho et al., 2020).

\section{4.Research Model}

This research aims to analyze the relationships between price and services quality on customers' purchasing decisions. This research adopted Lim and Lee (2020), Parasuraman et al. (1994) and Kotler (2000) services quality theories, particularly about service quality and customers' satisfaction to construct the research model. A good services quality will lead to increase costumer's satisfaction; thus, ultimately provide great impacts to customers to purchase a product (Carvalho et al., 2020).

In Timor-Leste's context, this concept has been used by many previous researchers such as in universities, hotels, restaurants, and sanitation industries (Flores et al., 2020; Marcal et al., 2020; Saldanha et al., 2018). Thus, this research also adopted some items from Flores et al. (2020) regarding services quality, while price and purchasing decisions adopted from (Marcal et al., 2020).

\section{5.Hypotheses}

\subsubsection{The influence of Price on Purchase Decision}

Price is the quantity of money that has been used to buy a product and service which can influence the community to buy a product (Zhu et al., 2019). Costumers consider the price as an essential factor in purchasing decisions because they want to spend their budget on products that are balanced 
with what they have spent and received (Chen et al., 2005; Kotler et al., 2012; Razak et al., 2017; Zietsman et al., 2019)

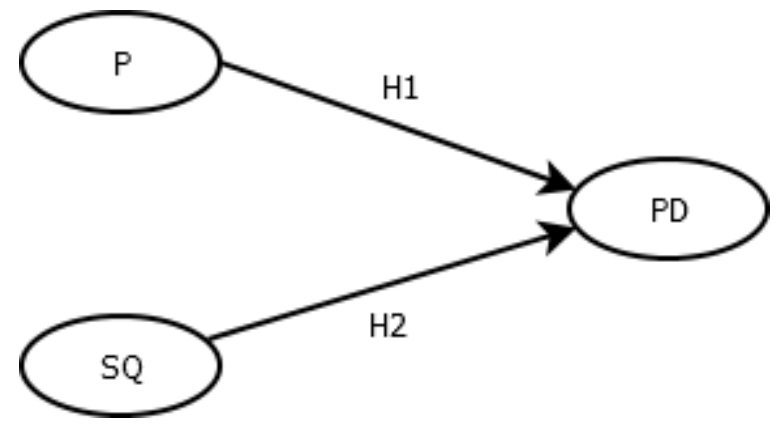

Figure 1. Conceptual framework and research model $(\mathrm{P}=$ Price; $\mathrm{SQ}=$ Services Quality; $\mathrm{PD}=$ Purchase Decisions).

Price has great impacts to purchasing decisions. This had been confirmed by numerous studies that price has a positive and significance impact on costumer purchasing decisions (Carvalho et al., 2020; Djatmiko \& Pradana, 2016; Kukar-Kinney et al., 2012; Marcal et al., 2020). Therefore, it is proposed the hypothesis such as:

H1: Price would have a positive and significant impact on customers' purchasing decisions.

\subsubsection{The influence of Services Quality on Purchasing Decisions}

Services quality refers to the extent of what customers can feel (Ham, 2003; Zameer et al., 2015; Carvalho et al., 2020). Costumer would prefer and choose to buy a product from suppliers that understand customers' specific needs and provide better services quality (Conti et al., 2019; Jahanshahi, Gashti, Mirdamadi, 2011; Silvestri et al., 2017; Waller \& Ahire, 1996; Wang et al., 2003).

Services quality also is essential for a company, because it could satisfy the costumers and lead to purchasing decisions. Numerous empirical studies have found that service quality has positive and significant impacts on costumers' purchasing decisions (Carvalho et al., 2020; Zameer et al., 2015). Therefore, it is hypothesized that:

$\mathrm{H} 2$ : Services quality would have a positive and significant influence on customers' purchasing decisions.

\section{Research Method}

\subsection{Population, Sample and Data Collection}

The total population of this study is 30,000 customers who have been visited Dili TAIS Market from the year of 2018 to 2021. From this, sample size of this study was 395 customers calculated by using the Slovin formula and with a margin error of 5\% from the total population of 30,000.
This study used questionnaires as data collection instrument. The questionnaires covered three variables namely price, service quality and costumer purchasing decision. Items of price and costumer purchasing decision were adopted from Marcal et al. (2020), while service quality adopted from Flores et al. (2020). All questions were formulated into five Likert scale, starting from (1) Strongly disagrees, (2) Disagree, (3) Neutral, (4) Agree, and (5) Strongly agree. The questionnaires were directly distributed to the respondents using the accidental sampling method.

\subsection{Data Analysis Technique}

The Smart-PLS 3.0 was used to analyze the data. Outer model tests were carried out to test validity and reliability of the relationship between variables and its indicators. Two types of validity tests namely convergent validity and discriminant validity. Convergent validity used two parameters such as outer loading (OL) and average variance extracted (AVE) with the minimum value of 0.7 and 0.5 respectively (Hair et al., 2014). However, for the exploratory research, Hair et al. (2014) suggested that OL value is accepted at the minimum value 0.6. To test the Discriminant validity, it was used the Fornell-Larcker criterion (FLC) (Hair et al., 2014) and Heterotrait-Monotrait (HTMT) (Henseler et al., 2015).

The reliability test used Cronbach alpha (CA) and composite reliability (CR). An item is reliable if the CA and CR values are above the threshold value of 0.7 , while for the exploratory research, the $\mathrm{CA}$ and $\mathrm{CR}$ values can be acceptable at the value of 0.6 (Hair et al., 2014; Saldanha et al., 2018). To test the relationship of variables (inner model measurement), the Path coefficient was used to test it. The significant relationships among variables could be occurred if the T-value is above of 1.96, while P-value is below than 0.05 (Hair et al., 2014).

\section{Results}

\subsection{Demographic Characteristics of Respondents}

The demographic information of the costumers that visited and purchased products in TAIS market consisted of male $(47.61 \%)$ and female $(52,39 \%)$, and age ranges were $15-25$ (55,92\%), 26-34 (23.68\%), 35-43 (13.85\%), >44 $(6.55 \%)$, most costumers were public employees (23\%), farmers $(2,38 \%)$, private employees $(60 \%)$, students $(9.62 \%)$, and others $(5 \%)$.

\subsection{Reliability and Validity Test}

Convergent validity used two parameters such as outer loading (OL) and average variance extracted (AVE). Figure 1 shows that $\mathrm{OL}$ values of all items were well-above 0.7 , and AVE values were higher than the threshold values of 0.5 
(Table III). Therefore, all items are considered valid to test the inner model.

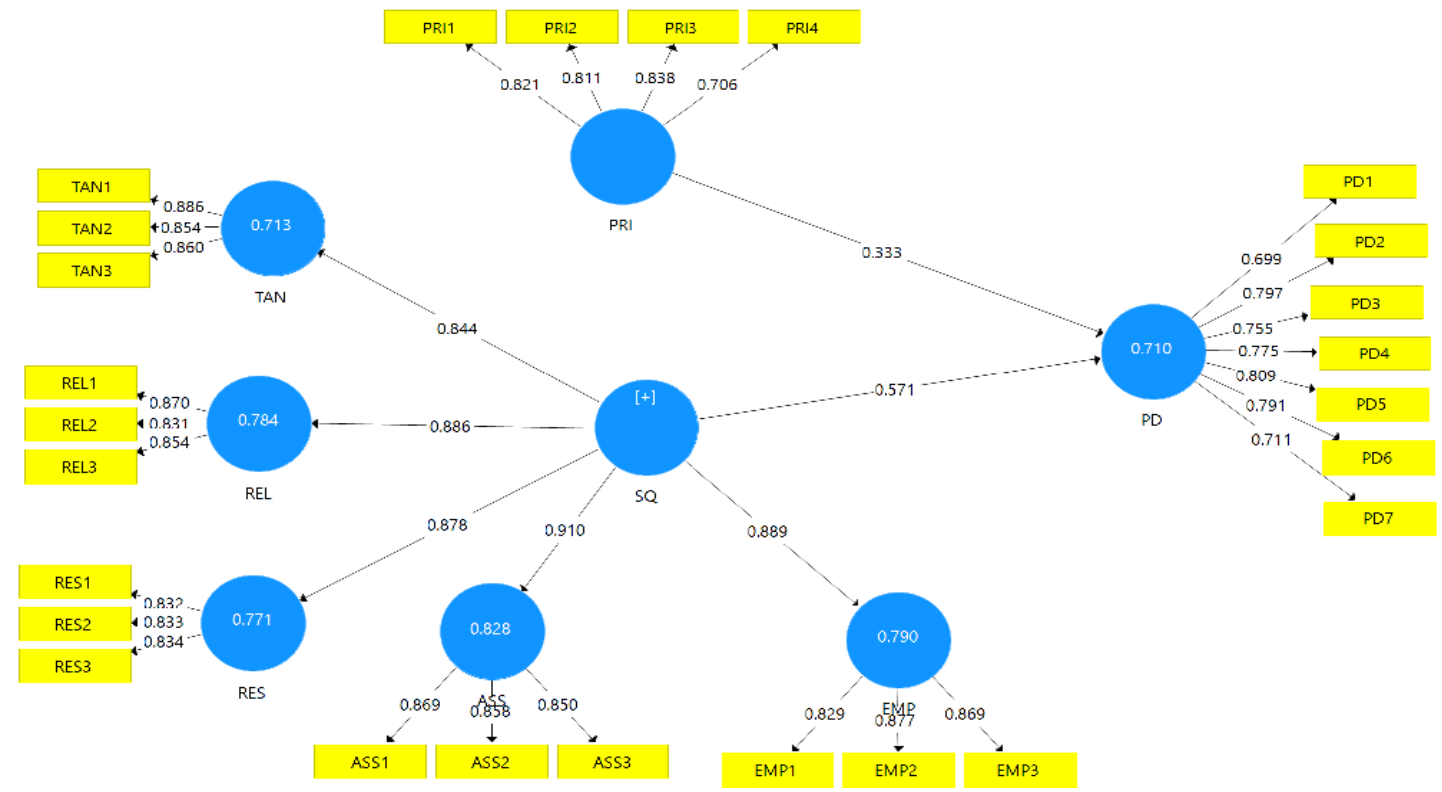

Figure 2. Outer Loading for Convergent Validity Test

Table I. Fornell-Larcker Criterion for Discriminant Validity

\begin{tabular}{|cccccccc|c|}
\hline & ASS & EMP & PD & PRI & REL & RES & SQ & TAN \\
\hline ASS & 0.859 & & & & & & & \\
\hline EMP & 0.758 & 0.859 & & & & & \\
\hline PD & 0.741 & 0.750 & 0.763 & & & & \\
\hline PRI & 0.643 & 0.640 & 0.744 & 0.795 & & & \\
\hline REL & 0.764 & 0.729 & 0.700 & 0.602 & 0.852 & & \\
\hline RES & 0.783 & 0.718 & 0.683 & 0.622 & 0.720 & 0.833 & \\
\hline SQ & 0.910 & 0.889 & 0.811 & 0.720 & 0.886 & 0.878 & \\
\hline TAN & 0.693 & 0.681 & 0.669 & 0.662 & 0.704 & 0.673 & 0.844 & 0.867 \\
\hline
\end{tabular}

Table II. Heterotrait-Monotrait (HTMT) for Discriminant Validity

\begin{tabular}{|c|c|c|c|c|c|c|c|}
\hline Item & ASS & EMP & PD & PRI & REL & RES & TAN \\
\hline \multicolumn{8}{|l|}{ ASS } \\
\hline EMP & 0.893 & & & & & & \\
\hline PD & 0.870 & 0.881 & & & & & \\
\hline PRI & 0.790 & 0.784 & 0.884 & & & & \\
\hline REL & 0.832 & 0.890 & 0.825 & 0.750 & & & \\
\hline RES & 0.877 & 0.896 & 0.823 & 0.784 & 0.891 & & \\
\hline TAN & 0.832 & 0.818 & 0.778 & 0.804 & 0.850 & 0.832 & \\
\hline
\end{tabular}


Table III shows the square root of the AVE values according to Hair et al. (2014). All items were valid based the FornellLarcker Criterion. Heterotrait-Monotrait Ratio (HTMT) was utilized to assess the validity of all items, and the maximum value of HTMT of all items is 0.9 (Henseler et al., 2015). Table II indicated that the maximum value of all items is below than 0.90; therefore, all items are acceptable and valid based on the HTMT test.
Table III indicated that constructs or all variables' Cronbach's alpha and Composite reliability $>0.7$. For examples, the CA value of latent variable of ASS is 0,822 $>0,7$ and the $\mathrm{CR}$ value is $0,894>0,7$. Also, other values of all items refer to the value that is higher than $>0,7$. Therefore, all items' values have good internal consis

Table III. CA, CR and AVE Loadings Value

\begin{tabular}{|c|ccc|}
\hline Item & CA & CR & AVE \\
\hline ASS & 0.822 & 0.894 & 0.738 \\
\hline EMP & 0.822 & 0.894 & 0.738 \\
\hline PD & 0.880 & 0.907 & 0.583 \\
\hline PRI & 0.805 & 0.873 & 0.633 \\
\hline REL & 0.811 & 0.888 & 0.726 \\
\hline RES & 0.780 & 0.872 & 0.694 \\
\hline TAN & 0.835 & 0.901 & 0.752 \\
\hline
\end{tabular}

Table IV. Results of Hypothesis Test

\begin{tabular}{|ccccccc|} 
Relationship & $\begin{array}{c}\text { Original } \\
\text { Sample } \\
(\mathbf{O})\end{array}$ & $\begin{array}{c}\text { Sample } \\
\text { Mean } \\
(\mathbf{M})\end{array}$ & $\begin{array}{c}\text { Standard } \\
\text { Deviation } \\
\text { (STDEV) }\end{array}$ & $\begin{array}{c}\text { T Statistics } \\
(|\mathbf{O} / \mathbf{S T D E V}|)\end{array}$ & P Values & Note \\
\hline PRI -> PD & 0.333 & 0.328 & 0.052 & 6.373 & 0.000 & Significant \\
\hline SQ -> PD & 0.571 & 0.576 & 0.052 & 11.016 & 0.000 & Significant \\
\hline
\end{tabular}

\subsection{Hypotheses Test}

The hypotheses were tested using the Path coefficient by seen in $\mathrm{T}$ and $\mathrm{P}$ values. The relationships between variables are significant when the T-value is greater than 1.96 and the $\mathrm{P}$-value is lower than the maximum threshold value of 0.05 (Hair et al., 2014). The first hypothesis is to identify the influence of Price (P) on purchasing decisions (PD) in the TAIS market. Table IV indicated that the $\mathrm{T}$ value (6.373) which is higher than minimum allowable value of 1.96 , while the P-value (0.000), lower than the maximum allowable value 0.05 . This means that price has positive and significant impact on purchasing decision. Therefore, the $\mathrm{H} 1$ is accepted. The second hypothesis is to identify the influence of services quality (SQ) on purchasing decisions (PD) in the Tais market. The $\mathrm{T}$ value (11.016) which is well above the threshold value of 1.96 and the P-value (0.000). Thus, the result indicated that service quality has significant influence on costumers' purchasing decisions in the Tais market. Therefore, the $\mathrm{H} 2$ is also supported.

\section{Discussions}

The first objective of this study is to analyze the influence of price on purchasing decisions in Tais Market, and the result indicated that there is a positive and significance influence of price on customers' purchasing decisions. This is because products in Tais Market Dili have better and reasonable prices. Also, the price is based on the quality of the product, acceptable prices and discounts. Furthermore, costumers considered price as an essential factor in purchasing decisions as they want to have a balance with what they get and expect after purchasing the product (Philip Kotler \& Keller, 2018). Price also becomes the factor that influences the community to purchase and use the product (Beneke et al., 2013; Cakici et al., 2019; Zhu et al., 2019). This study confirms previous empirical studies from Kukar-Kinney et al. (2012), Djatmiko \& Pradana (2016), Carvalho et al. (2020), and Marcal et al. (2020) that price has positive and significant impacts on costumer purchasing decision. Contrarily, this research is not in line with the studies from Son \& Jin (2019) which found that the cheap prices could not enhance customers' willingness to purchase any products. 
The second objective is to analyze the influence of services quality on purchasing decisions, and the result indicated that services quality has significant influenced on the customers' purchasing decisions. The significance of this result means that customers want to purchase a product because of the quality of the service in the Tais market. The services quality is involved such as services with conscientiousness, response to what customer's need, rapid services, good services, respect, competence, ready to respond the inquiries, maximize the services, and know the specific customers' necessities. This is because the service quality is a factor that customers can feel (Ham, 2003; Zameer et al., 2015; Carvalho et al., 2020; Lim \& Lee, 2020 ) and choose to buy a product from providers (Cheung et al., 2014). The result of this study is consistent with the previous study of Parasuraman et al. (1988), Parasuraman et al. (1994), Lim and Lee (2020) and Carvalho et al. (2020) which found that when a company provides better services quality, it could influence the customers' satisfaction; thus, it can enhance customers' willingness to purchase a product.

\section{Conclusions and Implications}

Based on the result of this study, the researchers conclude that price and services quality are the essential factors on customers' purchasing decisions in Tais Market. The analysis of this study which is using SMART-PLS 3.0 indicated that price and services quality have positive significant relationships on customers' purchasing decisions. This result of the study also provides insight meaningful of selling a product with good prices and based on customer's wants and need, it will convince costumers to purchase the product in the Tais market. Also, providing better services quality to customers will enhance customers' purchasing decisions.

Furthermore, the result of this study also implies that suppliers or businessmen in the Tais market are required to determine better prices and good services quality to customers. It must be based on customers' wants and needs to convince and attract customers to visit and purchase products in the Tais market.

\section{Limitations and Future Research Recommendations}

This research provided theoretical and practical implications, but it also has limitations. The limitations of this research are such as the research was done during Pandemic COVID-19. Also, the costumers are mostly from domestic customers, and international customers are few. The reason is the local customers tend to have sensitive to price and services quality. Therefore, future research, it requires targeting international tourists or customers for better comparison and generalizations.
Furthermore, this research is focusing only on price and services quality on customers' purchasing decisions. Customers are sensitive to the price and quality of the product. Thus, future research requires to focus also on the quality of products, customer's satisfactions, loyal customers and other factors that could influence customers' purchasing decisions.

In addition, this research was conducted using questionnaires in analyzing the data. Therefore, it is highly recommended that for the following research could be applied other techniques instruments in data collections to have better analysis and generalizations.

\section{References}

Aliman, N. K., \& Mohamad, W. N. (2016). Linking Service Quality, Patients' Satisfaction and Behavioral Intentions: An Investigation on Private Healthcare in Malaysia. Procedia Social and Behavioral Sciences, 224(August 2015), 141-148.

Anderson, J. C., Thomson, J. B. L., \& Wynstra, F. (2000). Combining value and price to make purchase decisions in business markets. International Journal of Research in Marketing, 17(4), 307-329.

Asadi, A., Pool, J. K., \& Jalilvand, M. R. (2014). The effect of perceived price fairness through satisfaction and loyalty on international tourists' price acceptance of Islamic-Iranian art products. Education, Business and Society: Contemporary Middle Eastern Issues, 7(4), 201-215.

Beneke, J., Flynn, R., Greig, T., \& Mukaiwa, M. (2013). The influence of perceived product quality, relative price and risk on customer value and willingness to buy: A study of private label merchandise. Journal of Product and Brand Management, 22(3), $218-228$.

Borishade, T. T., Ogunnaike, O. O., Salau, O., Motilewa, B. D., \& Dirisu, J. I. (2021). Assessing the relationship among service quality, student satisfaction and loyalty: the NIGERIAN higher education experience. Heliyon, e07590.

Cakici, A. C., Akgunduz, Y., \& Yildirim, O. (2019). The impact of perceived price justice and satisfaction on loyalty: the mediating effect of revisit intention. Tourism Review, 74(3), 443-462.

Carvalho, H. de F., Saldanha, E. de S., \& Amaral, A. M. (2020). The Mediation Effects of Customer Satisfaction on the Relations Between Product Price, Service Quality and Purchasing Decision.pdf. Timor-Leste Journal of Business and Management, 2(1), 14-26.

Cavallone, M. (2017). Mauro Cavallone Marketing and Customer Loyalty.

Chen, A., Lu, Y., \& Wang, B. (2017). Customers' purchase decision-making process in social commerce: A social learning 
perspective. International Journal of Information Management, 37(6), 627-638.

Chen, T. Y., Chang, P. L., \& Chang, H. S. (2005). Price, brand cues, and banking customer value. International Journal of Bank Marketing, 23(3), 273-291.

Cheung, C. M. K., Xiao, B. S., \& Liu, I. L. B. (2014). Do actions speak louder than voices? the signaling role of social information cues in influencing consumer purchase decisions. Decision Support Systems, 65(C), 50-58.

Chien, L. H., \& Chi, S. Y. (2019). Corporate image as a mediator between service quality and customer satisfaction: difference across categorized exhibitors. Heliyon, 5(3).

Conti, E., Vesci, M., Crudele, C., \& Pencarelli, T. (2019). Design-driven innovation, quality, and customer value in manufacturing companies. TQM Journal, 31(6), 968-986.

De Medeiros, J. F., Ribeiro, J. L. D., \& Cortimiglia, M. N. (2016). Influence of perceived value on purchasing decisions of green products in Brazil. Journal of Cleaner Production, 110, 158-169.

Djatmiko, T., \& Pradana, R. (2016). Brand Image and Product Price; Its Impact for Samsung Smartphone Purchasing Decision. In Procedia - Social and Behavioral Sciences (Vol. 219, pp. 221-227).

Flores, A. F., Saldanha, de S. S., \& Vong, M. F. (2020). The effect of customer satisfaction Mediation on the relationship between service quality and customer loyalty. Timor-Leste Journal of Business and Management, 2(1), 56-65.

Hair, J. F., Sarstedt, M., Hopkins, L., \& Kuppelwieser, V. G. (2014). Partial least squares structural equation modeling (PLSSEM). European Business Review, 26(2), 106-121.

Ham, C. L. (2003). Service quality, customer satisfaction, and customer behavioral intentions in higher education. Nova Southeastern University.

Hanna, R. C., Lemon, K. N., \& Smith, G. E. (2019). Is transparency a good thing? How online price transparency and variability can benefit firms and influence consumer decision making. In Business Horizons (Vol. 62, Issue 2, pp. 227-236).

Hati, S. R. H., Zulianti, I., Achyar, A., \& Safira, A. (2021). Perceptions of nutritional value, sensory appeal, and price influencing customer intention to purchase frozen beef: Evidence from Indonesia. Meat Science, 172, 108306.

Henseler, J., Ringle, C. M., \& Sarstedt, M. (2015). A new criterion for assessing discriminant validity in variance-based structural equation modeling. Journal of the Academy of Marketing Science, 43(1), 115-135.

Jahanshahi, Gashti, Mirdamadi, N. and K. (2011). Study of the Effects of Customer Service and Product Quality on Customer Satisfaction and Loyalty $\mathrm{PhD}$ Scholar in Business
Administration. International Journal of Humanities and Social Science, 1(7), 253-260.

Jain, M., Rao, A. B., \& Patwardhan, A. (2018). Consumer preference for labels in the purchase decisions of air conditioners in India. Energy for Sustainable Development, 42, 24-31.

Jun, S. P., \& Park, D. H. (2016). Consumer information search behavior and purchasing decisions: Empirical evidence from Korea. Technological Forecasting and Social Change, 107, 97 111.

Jung, H. S., \& Yoon, H. H. (2012). Why do satisfied customers switch? Focus on the restaurant patron variety-seeking orientation and purchase decision involvement. International Journal of Hospitality Management, 31(3), 875-884.

Kasiri, L. A., Guan Cheng, K. T., Sambasivan, M., \& Sidin, S. M. (2017). Integration of standardization and customization: Impact on service quality, customer satisfaction, and loyalty. Journal of Retailing and Consumer Services, 35(December 2016), 91-97.

Kaswengi, J., \& Lambey-Checchin, C. (2019). How logistics service quality and product quality matter in the retailercustomer relationship of food drive-throughs: The role of perceived convenience. International Journal of Physical Distribution and Logistics Management.

Kotler, P., Armstrong, G., Ang, S. H., Leong, S. M., Tan, C. T., \& Ho-Ming, O. (2012). Principles of marketing: an Asian perspective. Pearson/Prentice-Hall.

Kotler, P. (2000). Marketing management: The millennium edition (Vol. 199). Upper Saddle River, NJ: Prentice Hall.

Kotler, P., \& Keller, K. L. (2018). Excerpt from Marketing Management, 15th Global Edition, Philip Kotler \& Kevin Lane Keller. Pearson.

Kotler, P., Keller, K. L., Manceau, D., \& Dubois, B. (2016). Marketing Management, 15e édition. New Jersy: Pearson Education.

Kukar-Kinney, M., Ridgway, N. M., \& Monroe, K. B. (2012). The Role of Price in the Behavior and Purchase Decisions of Compulsive Buyers. In Journal of Retailing (Vol. 88, Issue 1, pp. 63-71).

Lee, S., \& Kim, E. K. (2017). The Effects of Korean Medical Service Quality and Satisfaction on Revisit Intention of the United Arab Emirates Government Sponsored Patients. Asian Nursing Research, 11(2), 142-149.

Lim, J., \& Lee, H. C. (2020). Comparisons of service quality perceptions between full service carriers and low cost carriers in airline travel. Current issues in Tourism, 23(10), 1261-1276.

Marcal, A. R., Saldanha, E. D. S., \& Amaral, A. M. (2020). Examining the Structural Relatiosnhips of Product Price, 
Product Quality and Customer Purchasing Decision. In Timor Leste Journal of Business and Management (Vol. 2, pp. 1-9).

Maslowska, E., Malthouse, E. C., \& Viswanathan, V. (2017). Do customer reviews drive purchase decisions? The moderating roles of review exposure and price. In Decision Support Systems (Vol. 98, pp. 1-9).

Meesala, A., \& Paul, J. (2018). Service quality, consumer satisfaction and loyalty in hospitals: Thinking for the future. Journal of Retailing and Consumer Services, 40, 261-269.

Özkan, P., Süer, S., Keser, İ. K., \& Kocakoç, İ. D. (2019). The effect of service quality and customer satisfaction on customer loyalty: The mediation of perceived value of services, corporate image, and corporate reputation. International Journal of Bank Marketing.

Parasuraman, A. ., Zeithaml, V. A. ., \& Berry, L. L. (1988). SERVQUAL: a Multiple-item Scale for Measuring Consumer Perceptions of Service Quality. Retailing: Critical ..., 64(1), 1240.

Parasuraman, A., Zeithaml, V. A., \& Berry, L. L. (1994). Alternative scales for measuring service quality: A comparative assessment based on psychometric and diagnostic criteria. Journal of Retailing, 70(3), 201-230.

Parasuraman, B., Leonard L, \& Zeithaml, V. A. (1991). Perceived service quality as a customer-based performance measure: An empirical examination of organizational barriers using an extended service quality model. Human Resource Management, 30(3), 335-364.

Ramayah, T., Samat, N., \& Lo, M.-C. (2011). Market orientation, service quality and organizational performance in service organizations in Malaysia. Asia-Pacific Journal of Business Administration, 3(1), 8-87.

Razak, I., Nirwanto, N., \& Triatmanto, B. (2017). The Impact of Product Quality and Price on Customer Satisfaction with the Mediator of Customer Value Ismail. Journal of Marketing and Consumer Research, 3(11), 1240-1248.

Saldanha, E. de S. (2019). The Mediation Effects of Business Strategy on the Relations between Industrial Competition and Performance. Timor-Leste Journal of Business and Management, 1(1), 1-11.

Saldanha, E. de S., Rahyuda, I. K., Yasa, N. N. K., \& Sukaatmadja, I. P. G. (2018). The Role of Business Strategy in Mediating the Relationship Between Industrial Competition and Performances: A Study in the Higher Education Industry in Timor-Leste. European Jorunal of Business and Management,
10(8), 152-172.

Silvestri, C., Aquilani, B., \& Ruggieri, A. (2017). Service quality and customer satisfaction in thermal tourism. TQM Journal, 29(1), 55-81.

Son, J., \& Jin, B. E. (2019). When do high prices lead to purchase intention? Testing two layers of moderation effects. Asia Pacific Journal of Marketing and Logistics, 31(5), 15161531.

Song, M., Lee, W. S., \& Moon, J. (2019). Exploring effective price presentation format to reduce decision difficulty and increase von Helversen decision satisfaction. In Tourism Management Perspectives (Vol. 32).

Subrahmanyam, A. (2017). Relationship between service quality, satisfaction, motivation and loyalty: A multidimensional perspective. Quality Assurance in Education, 25(2), 171-188.

von Helversen, B., Abramczuk, K., Kopeć, W., \& Nielek, R. (2018). Influence of consumer reviews on online purchasing decisions in older and younger adults. Decision Support Systems, 113(March), 1-10.

Waller, M. A., \& Ahire, S. (1996). Management perception of the link between product quality and customers' view of product quality. International Journal of Operations and Production Management, 16(9), 23-33.

Wang, Y., Lo, H. P., \& Hui, Y. V. (2003). The antecedents of service quality and product quality and their influences on bank reputation: Evidence from the banking industry in China. Managing Service Quality: An International Journal, 13(1), 72 83.

Zameer, H., Tara, A., Kausar, U., \& Mohsin, A. (2015). Impact of service quality, corporate image and customer satisfaction towards customers' perceived value. International Journal of Bank Marketing, 33(4).

Zhu, G., Wu, Z., Wang, Y., Cao, S., \& Cao, J. (2019). Online purchase decisions for tourism e-commerce. Electronic Commerce Research and Applications, 38(July).

Zietsman, M. L., Mostert, P., \& Svensson, G. (2019). Perceived price and service quality as mediators between price fairness and perceived value in business banking relationships: A microenterprise perspective. International Journal of Bank Marketing, 37(1), 2-19. 


\section{Appendix}

\section{Measurement}

I. $\quad$ Price (PRI)

\begin{tabular}{|c|c|c|c|c|c|c|}
\hline \multirow{2}{*}{$\mathrm{NO}$} & \multirow{2}{*}{ Questions } & \multicolumn{5}{|c|}{ LIKERT SCALE } \\
\hline & & 1 & 2 & 3 & 4 & 5 \\
\hline PRI11 & The price of the product is good in the Tais market. & & & & & \\
\hline PRI2 & The price of the product is reasonable in the Tais market. & & & & & \\
\hline PRI13 & The price of the product is acceptable. & & & & & \\
\hline PRI14 & The Tais market provides discounts to the costumers. & & & & & \\
\hline
\end{tabular}

\section{SERVICES QUALITY (SQ)}

\begin{tabular}{|c|c|c|c|c|c|c|}
\hline NO & Questions & & LIK & $\bar{S}$ & & \\
\hline & & 1 & 2 & 3 & 4 & 5 \\
\hline Tan & Tangible & & & & & \\
\hline Tan1 & It's a good business place. & & & & & \\
\hline Tan2 & A clean business place. & & & & & \\
\hline Tan3 & Suppliers have good appearances. & & & & & \\
\hline Rel & Reliability & & & & & \\
\hline Rel1 & Suppliers provide consistent services. & & & & & \\
\hline Rel2 & Suppliers provide what costumers required. & & & & & \\
\hline Rel3 & Suppliers provide rapid services to customers. & & & & & \\
\hline Res & Responsibility & & & & & \\
\hline Res1 & Suppliers provide services to customers with respect. & & & & & \\
\hline Res2 & Suppliers support costumers based on their preferences. & & & & & \\
\hline Res3 & $\begin{array}{l}\text { Suppliers are always ready to respond what customers' } \\
\text { inquiries. }\end{array}$ & & & & & \\
\hline Ass & Assurances & & & & & \\
\hline Ass1 & Suppliers provide good services to customers. & & & & & \\
\hline Ass 2 & Suppliers communicate respectively to costumers. & & & & & \\
\hline Ass3 & $\begin{array}{l}\text { Suppliers are competent in providing services to } \\
\text { customers. }\end{array}$ & & & & & \\
\hline Emp & Empathy & & & & & \\
\hline Emp1 & $\begin{array}{l}\text { Suppliers are always ready to respond to costumer's } \\
\text { inquiries. }\end{array}$ & & & & & \\
\hline Emp2 & Suppliers provide fully attentions to costumers. & & & & & \\
\hline Emp3 & Suppliers know well customers' specific needs. & & & & & \\
\hline
\end{tabular}

II. Purchasing Decisions (PD)

\begin{tabular}{|c|c|c|c|c|c|c|}
\hline \multirow[t]{2}{*}{ NO } & \multirow[t]{2}{*}{ Questions } & \multicolumn{5}{|c|}{ LIKERT SCALE } \\
\hline & & 1 & 2 & 3 & 4 & 5 \\
\hline PD1 & $\begin{array}{l}\text { I purchase the product because of a need to buy it in } \\
\text { Tais market. }\end{array}$ & & & & & \\
\hline PD2 & $\begin{array}{l}\text { After conducting evaluation and observation in other } \\
\text { markets or places, I decided to purchase a product in } \\
\text { the Tais market. }\end{array}$ & & & & & \\
\hline PD3 & $\begin{array}{l}\text { I decided to purchase a product in the Tais market } \\
\text { because of the price. }\end{array}$ & & & & & \\
\hline PD4 & $\begin{array}{l}\text { I decided to purchase a product in the Tais market } \\
\text { because of the quality of the product. }\end{array}$ & & & & & \\
\hline PD5 & $\begin{array}{l}\text { I decided to purchase a product in the Tais market } \\
\text { because of the quality of their services. }\end{array}$ & & & & & \\
\hline PD6 & $\begin{array}{l}\text { I decided to purchase a product in the Tais market } \\
\text { because of their promotions words of mouth (WOM). }\end{array}$ & & & & & \\
\hline PD7 & $\begin{array}{l}\text { I decided to purchase a product in the Tais market } \\
\text { because it was based on my own experiences. }\end{array}$ & & & & & \\
\hline
\end{tabular}

